\title{
(6)
}

\section{Watershed Scale Response to Climate Change-Naches River Basin, Washington}

\section{Introduction}

General Circulation Model (GCM) simulations of future climate through 2099 project a wide range of possible scenarios (Intergovernmental Panel on Climate Change, 2007). To determine the sensitivity and potential effect of long-term climate change on the freshwater resources of the United States, the U.S. Geological Survey Global Change study, "An integrated watershed scale response to global change in selected basins across the United States" was started in 2008. The long- term goal of this national study is to provide the foundation for hydrologically based climate-change studies across the nation.

Fourteen basins for which the Precipitation Runoff Modeling System (PRMS) has been calibrated and evaluated were selected as study sites. PRMS is a deterministic, distributedparameter watershed model developed to evaluate the effects of various combinations of precipitation, temperature, and land use on streamflow and general basin hydrology. Output from five GCMs and four emission scenarios were used to develop an ensemble of climate-change scenarios for each basin. These ensembles were simulated with the corresponding PRMS model. This fact sheet summarizes the hydrologic effect and sensitivity of the PRMS simulations to climate change for the Naches River Basin below Tieton River in Washington (U.S. Geological Survey streamflow-gaging station 12494000; fig. 1) presented in the project summary report (Markstrom and others, 2012) and a journal article (Hay and others, 2011).

\section{Study Area}

The Naches River is a 2,437-square kilometer $\left(\mathrm{km}^{2}\right)$ basin that is the largest tributary of the Yakima River in central Washington. Elevations in the Naches Basin range from 562 to 1,650 meters. The entire Yakima River Basin averages 69 centimeters of annual rainfall, varying from more than 254 centimeters in its headwaters on the east side of the Cascade Mountains to 15 centimeters in the lower, arid part of the basin. The Yakima River Basin includes a large rain-to-snow transition zone (63 percent of the basin is between elevations of 610 and 1,372 meters) with winter precipitation dominated by snow at the highest elevations and rain at the lowest elevations. PRMS models developed for the Yakima are described in detail in Mastin and Vaccaro (2002).

Agriculture is the principal economic activity in the Yakima Basin; about $2600 \mathrm{~km}^{2}$ in the low-lying semiarid-to-arid parts of the basin are used for agriculture (Vaccaro and others, 2009). Agriculture in the Yakima Basin depends on irrigation with an annual demand of about 3,206 million cubic-meters of water that is supplied mostly by surface water. Five principle reservoirs in the upper portions of the Yakima Basin with a combined capacity of 1,275 million cubic-meters supplement flows in the rivers to supply irrigators and provide adequate instream flows for andromous fish habitat. The largest runoff volumes occur generally in the spring as the snowpack in the higher elevations melts. Sufficient water to meet the demands of the basin in any one year is dependent highly on an adequate spring snowpack.

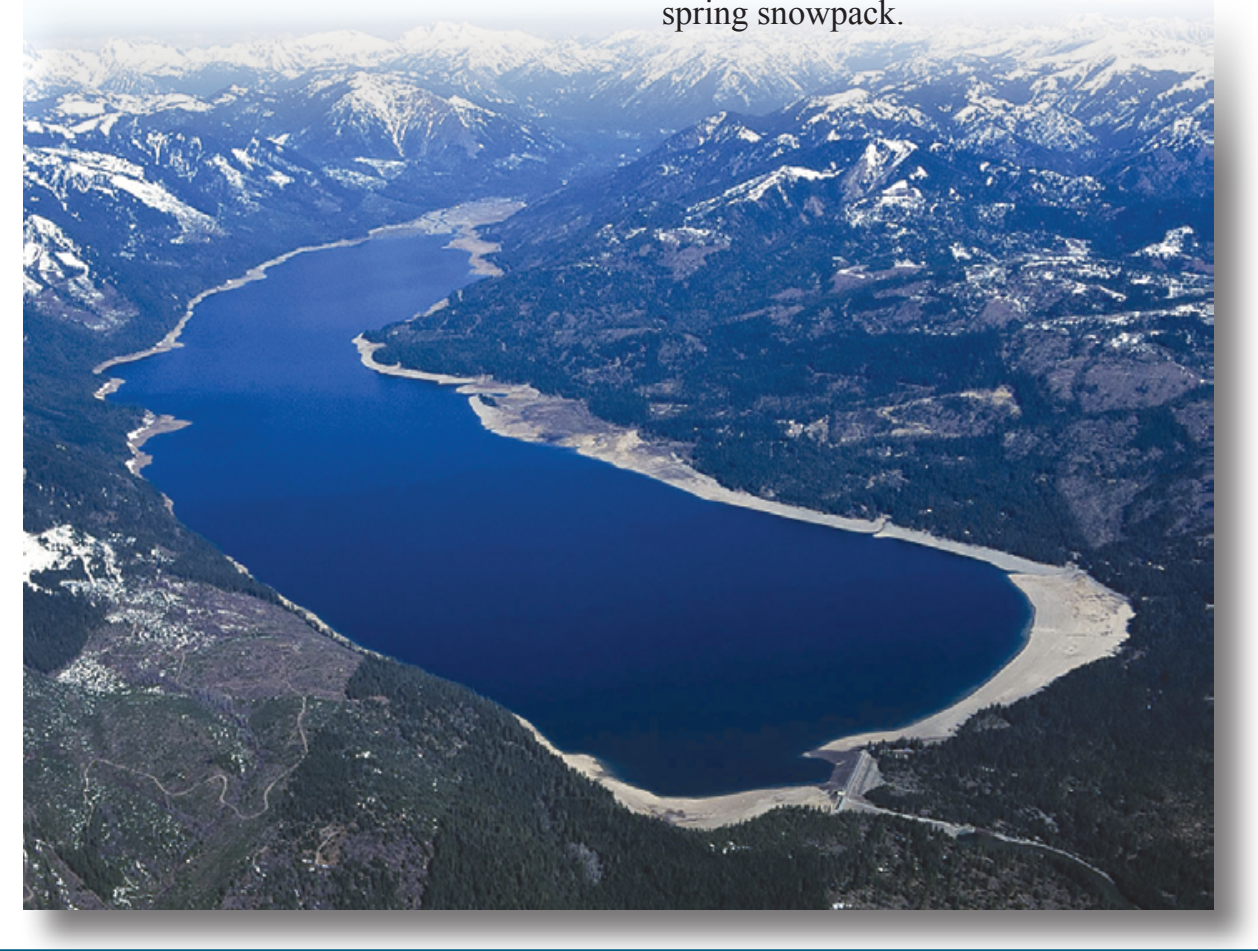




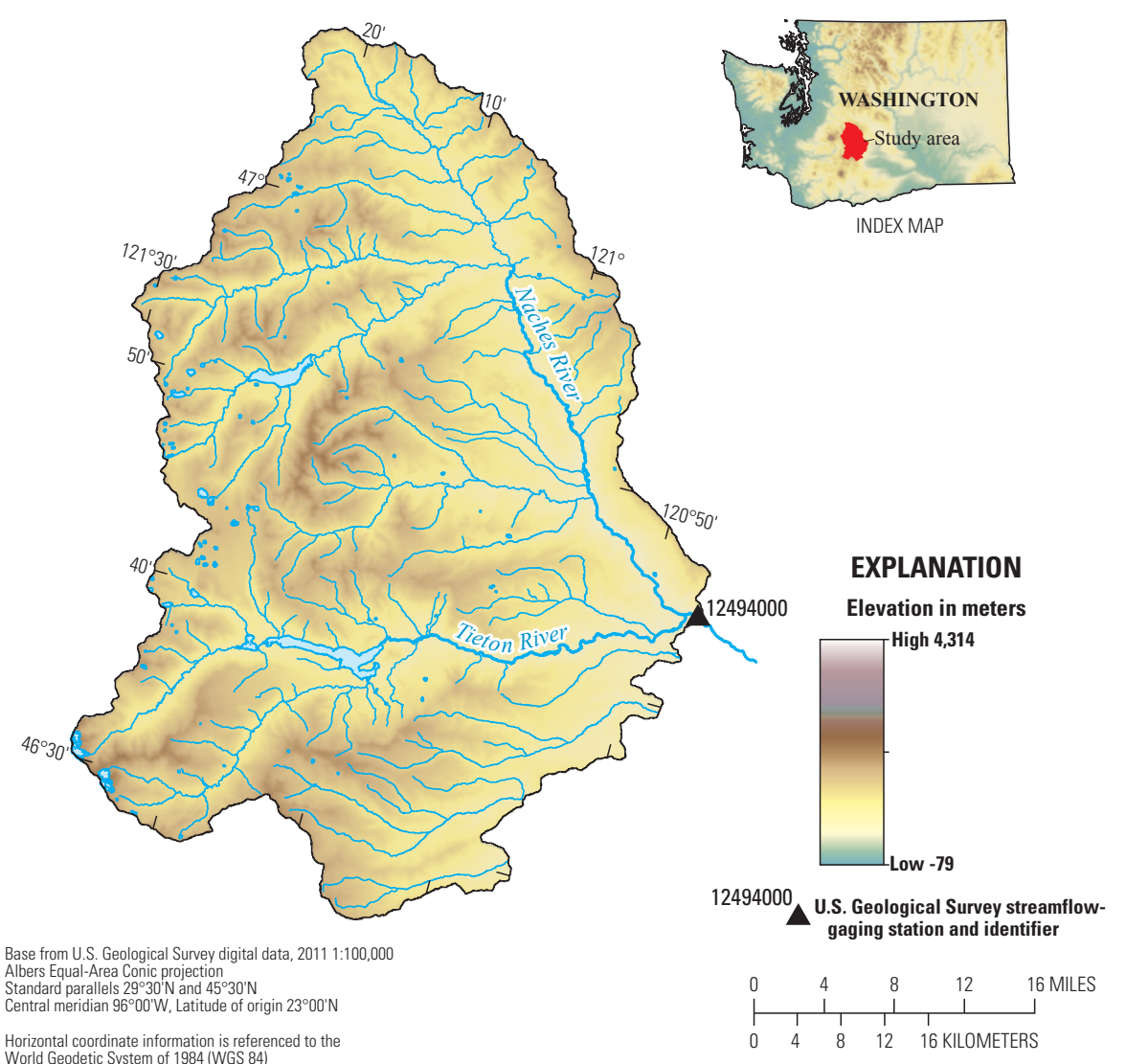

Figure 1. Precipitation Runoff Modeling System study locations, Naches River Basin, Washington, and location of U.S. Geological Survey streamflow-gaging station 12494000 with a drainage area of 2,437 square kilometers and elevation range from 1,650 to 2,562 meters.

\section{General Circulation Models}

Given the uncertainty in climate modeling, it is desirable to use more than one GCM to obtain a range of potential future climatic conditions. Monthly precipitation and temperature output from five GCMs were processed (table 1).

Table 1. General Circulation Model (GCM) projections used in this study.

\begin{tabular}{ll}
\hline \multicolumn{1}{c}{ GCM } & \multicolumn{1}{c}{ Center and country of origin } \\
\hline BCC-BCM2.0 & Bjerknes Centre for Climate Research, Norway \\
CSIRO-Mk3.0 & Australia's Commonwealth Scientific and Industrial Research Organization, Australia \\
CSIRO-Mk3.5 & Australia's Commonwealth Scientific and Industrial Research Organization, Australia \\
INM-CM3.0 & Institute for Numerical Mathematics, Russia \\
MIROC3.2 & National Institute for Environmental Studies, Japan \\
\hline
\end{tabular}


The GCM outputs were obtained from the World Climate Research Programme's Coupled Model Intercomparison Project phase 3 multi-model dataset archive, which was referenced in the Intergovernmental Panel on Climate Change Fourth Assessment Special Report on Emission scenarios (Intergovernmental Panel on Climate Change, 2007). For each GCM, one current (water years 1988-1999) and three future emission scenarios were used and are described in table 2.

Table 2. Climate-change emission scenarios simulated by the General Circulation Models in this study.

\begin{tabular}{ll}
\hline \multicolumn{1}{c}{ Emission scenario } & \multicolumn{1}{c}{ Description/assumptions } \\
\hline 20C3M & $\begin{array}{l}\text { 20th century climate used to determine baseline (1989-1999) conditions } \\
\text { Rapid economic growth, a global population that peaks in mid-21st century and rapid introduction of new and } \\
\text { m1B }\end{array}$ \\
B1 & $\begin{array}{c}\text { Convere efficient technologies with a balanced emphasis on all energy sources } \\
\text { economic structures toward a service and information economy that is more ecologically friendly } \\
\text { A2 }\end{array}$ \\
\hline
\end{tabular}

Climate-change fields were derived by calculating the change in climate from current (water years 1988-1999) to future conditions simulated by each GCM. The 20C3M simulation for water years 1988-1999 was used to represent current climatic conditions. This 12-year period of record was chosen based on the overlap of the available historical records from the 14 basins included in the national study. Climate change fields (percentage changes in precipitation and degree changes in temperature) were computed for 12-year moving window periods (from 2001-2099) using the 20C3M (1988-1999) and the A1B, B1, and A2 emission scenarios. A 12-year moving window, starting in 2001 and ending in 2099, results in 1,320 future scenarios $[(88,12$-year climatologies, 1 per year starting with 2001-2012 and ending with 2088-2099) x (3 emission scenarios) $\mathrm{x}$ (5 GCMs)].

Climate-change scenarios were generated for PRMS by modifying PRMS precipitation and temperature inputs with the mean monthly climate change fields derived from the GCMs, resulting in 1,320 PRMS-input files. Table 3 shows the change (slope) and adjusted $\mathrm{R}^{2}(\operatorname{adj} \mathrm{R} 2)$ for the least squares fit to the trend line for selected output variables from the PRMS projections. The slope indicates the change in the selected variable by year. The adjusted $\mathrm{R} 2$ value gives an indication of the variability in the central tendency of the trend line.

Figure 2 shows a summary of the projected range in 11-year moving mean daily values of maximum temperature (fig. $2 A$ ), minimum temperature (fig. $2 B$ ), and precipitation (fig. $2 C$ ) by emission scenario. The first year of each 12-year simulation was used as PRMS initialization and is not included in the results. The three solid-colored lines indicate the 11-year moving mean values (x-axis indicates center of 11 -year window) for the three future emission scenarios (central tendency of the five GCMs for each emission scenario). The projected range shown for each emission scenario indicates the range of potential future climatic conditions simulated by the five GCMs. All GCM simulations project an overall increase in maximum and minimum temperature (table 3), with uncertainties associated with these GCM projections increasing with time. Both maximum and minimum temperatures show the smallest projected changes for the B1 emission scenario. Projections of changes in precipitation are highly variable, with the central tendencies for the A1B and A2 emission scenarios projecting a slight increase by the end of the 21 st century (table 3 ). The wide range in the precipitation projections indicates a large amount of uncertainty.

\section{Results}

PRMS simulates spatially distributed streamflow, components of flow (surface, subsurface, and groundwater), snowpack conditions, and many other hydrologic components of interest. Figure 3 shows examples of summary outputs from PRMS using the GCM scenarios. The central tendencies of the PRMS simulations using the three emission scenarios (indicated by the solid-colored lines) project a slight increase in mean annual streamflow for the $\mathrm{A} 2$ and $\mathrm{A} 1 \mathrm{~B}$ emission scenarios (fig. $3 A$ and table 3). The central tendency of the PRMS simulations using the three emission scenarios project a slight increase in mean annual evapotranspiration for the $\mathrm{A} 2$ and $\mathrm{B} 1$ emission scenarios (fig. $3 B$ and table 3). Large decreases in the snowpack water equivalent and the percent of precipitation that falls as snow are projected for all emission scenarios by the end of the $21 \mathrm{st}$ century (figs. $3 C-D$ and table 3 ).

While this change in the form of precipitation does not affect the annual runoff dramatically, it does change substantially the seasonal distribution of basin mean streamflow (fig. 4). The red lines in figure 4 show PRMS-simulated mean 

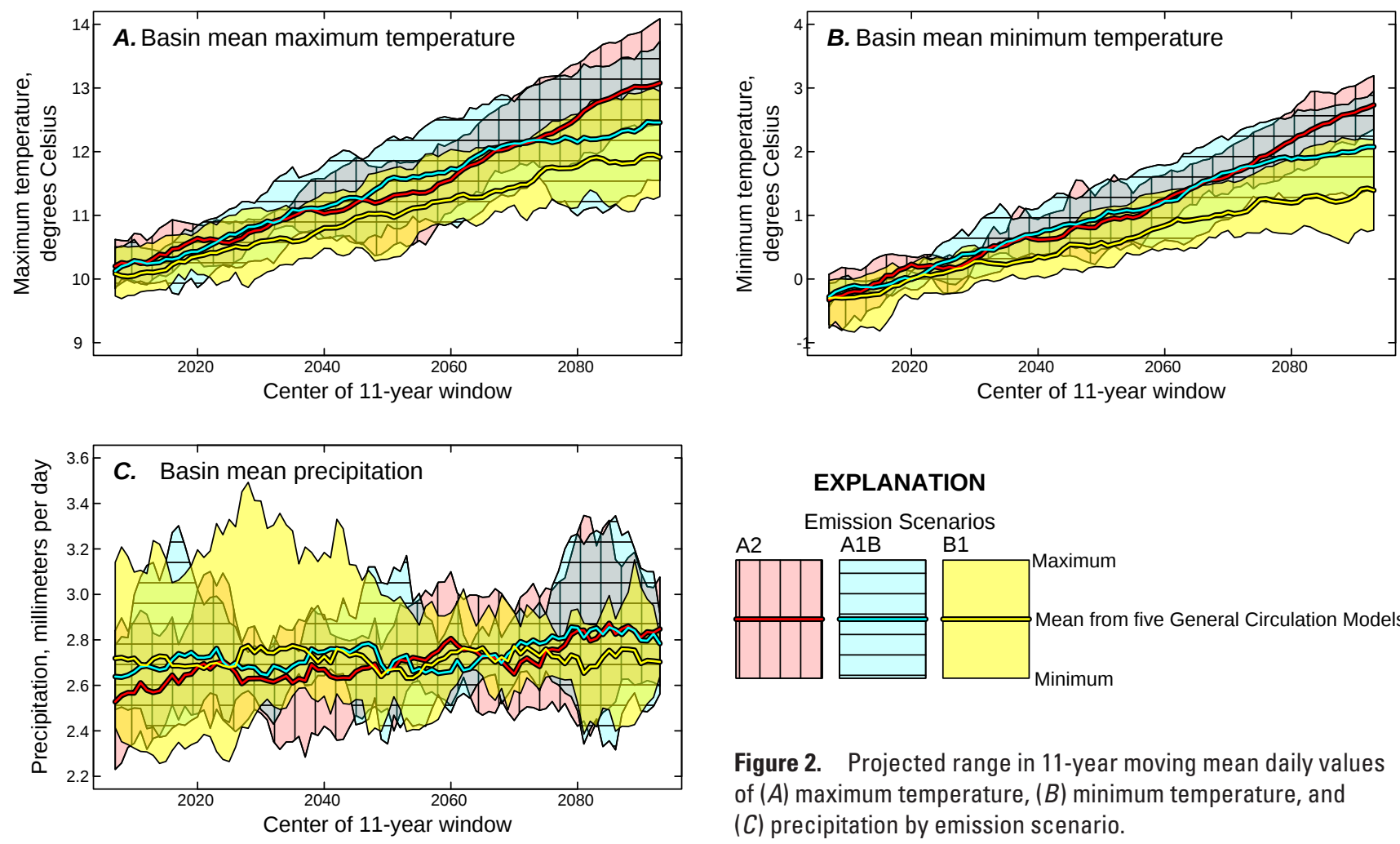

EXPLANATION

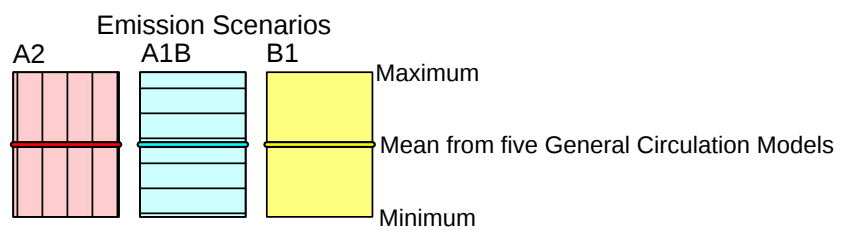

Figure 2. Projected range in 11-year moving mean daily values of $(A)$ maximum temperature, $(B)$ minimum temperature, and (C) precipitation by emission scenario.

Table 3. Projected change by year (slope) and adjusted $R^{2}$ (adjR2) based on the central tendencies of the five General Circulation Models for the three carbon emission scenarios for selected Precipitation Runoff Modeling System (PRMS) output variables.

[Blue indicates a significant negative trend and yellow indicates a significant positive trend $(\mathrm{p}<0.05)$ accounting for lag-1 autocorrelation]

\begin{tabular}{|c|c|c|c|c|c|c|}
\hline \multirow[t]{2}{*}{ PRMS output variable } & \multicolumn{2}{|c|}{$\begin{array}{c}\text { Emission scenario } \\
\text { A1B }\end{array}$} & \multicolumn{2}{|c|}{$\begin{array}{c}\text { Emission scenario } \\
\text { A2 }\end{array}$} & \multicolumn{2}{|c|}{$\begin{array}{c}\text { Emission scenario } \\
\text { B1 }\end{array}$} \\
\hline & slope & adjR2 & slope & adjR2 & slope & $\operatorname{adjR2}$ \\
\hline Maximum temperature in degrees Celsius & 0.028 & 0.97 & 0.033 & 0.97 & 0.023 & 0.99 \\
\hline Minimum temperature in degrees Celsius & 0.029 & 0.98 & 0.034 & 0.98 & 0.021 & 0.99 \\
\hline Precipitation in millimeters per day & 0.0018 & 0.49 & 0.0029 & 0.77 & 0.0002 & 0.00 \\
\hline Evapotranspiration in millimeters per day & 0.0005 & 0.38 & 0.0010 & 0.77 & 0.0006 & 0.61 \\
\hline Streamflow in cubic meters per second & 0.0561 & 0.59 & 0.0789 & 0.79 & -0.0023 & -0.01 \\
\hline Percent snow in percent per day & -0.17 & 0.96 & -0.22 & 0.97 & -0.15 & 0.97 \\
\hline Snowpack water equivalent in millimeters per day & -0.46 & 0.91 & -0.58 & 0.95 & -0.51 & 0.97 \\
\hline
\end{tabular}

monthly streamflow for current conditions (1989-1999). The boxplots represent the range in the projected mean monthly streamflow for the five GCMs and the three future emission scenarios for 2030 (green, 2025-2035), 2060 (tan, 2055-2065) and 2090 (blue, 2085-2095). Results show basin mean winter streamflow increasing over time and late spring-summer runoff decreasing over time. By the end of the 21 st century, the timing of peak streamflow is projected to shift from May to possibly as early as February.
Intermediate states of interest produced by PRMS are summarized in Markstrom and others (2011). Analysis of these intermediate states may indicate areas of the water balance most susceptible to changes in climate. For example, figure 5 shows current and projected basin mean snowpack water equivalent by month. Simulations indicate decreasing snowpack water equivalent for all months, a direct result of increasing temperatures and corresponding changes of precipitation from snow to rain throughout the year. 

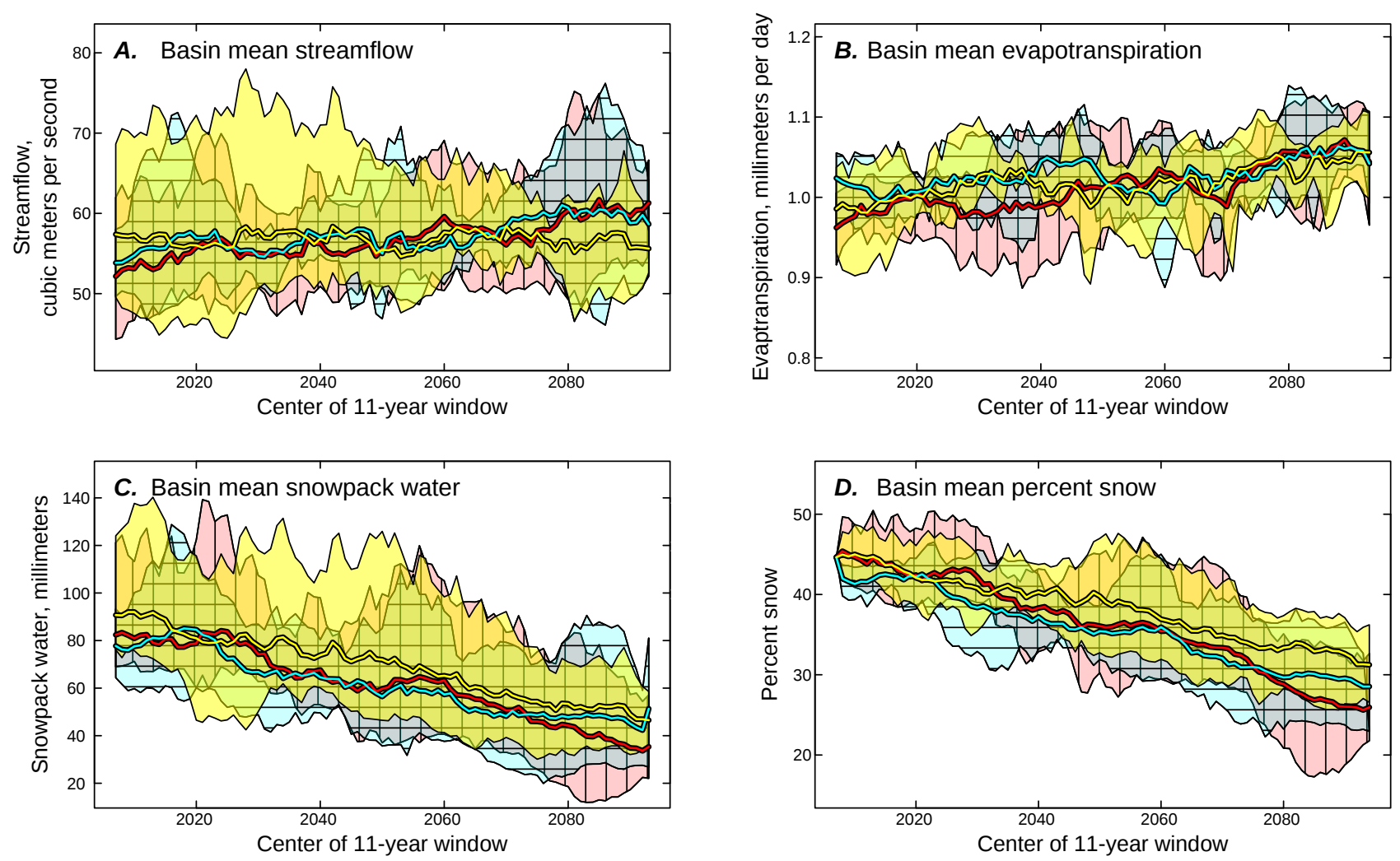

Figure 3. Projected range in 11-year moving mean daily values of $(A)$ streamflow, $(B)$ evapotranspiration, $(C)$ snowpack water equivalent, and $(D)$ precipitation that falls as snow by emission scenario.
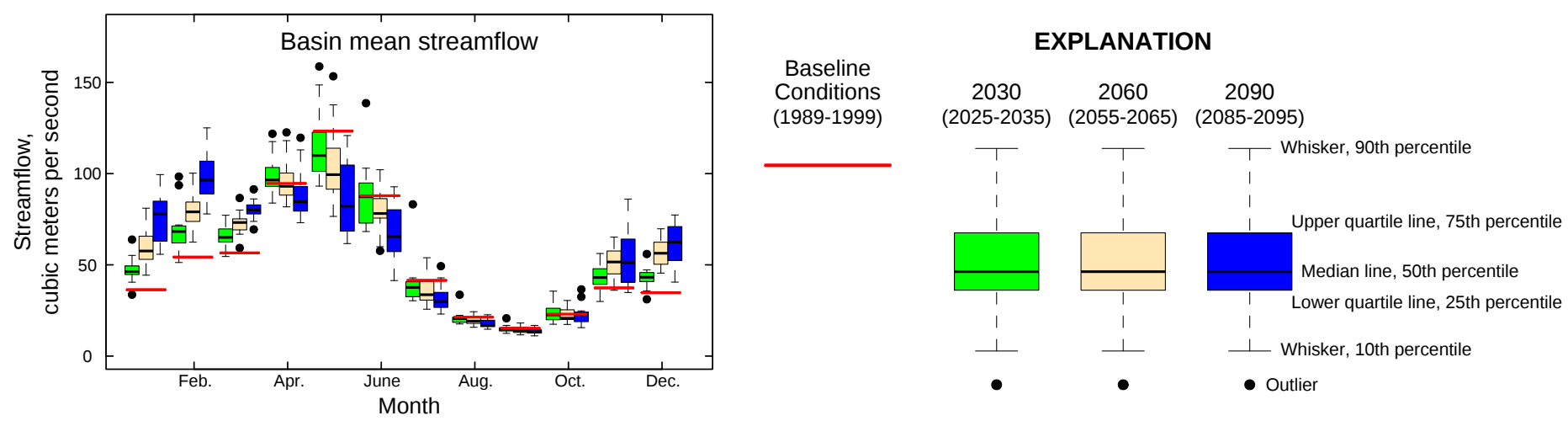

Figure 4. Mean daily streamflow values by month for baseline conditions and projected range $(2030,2060$, and 2090$)$ using the five General Circulation Models and three emission scenarios.

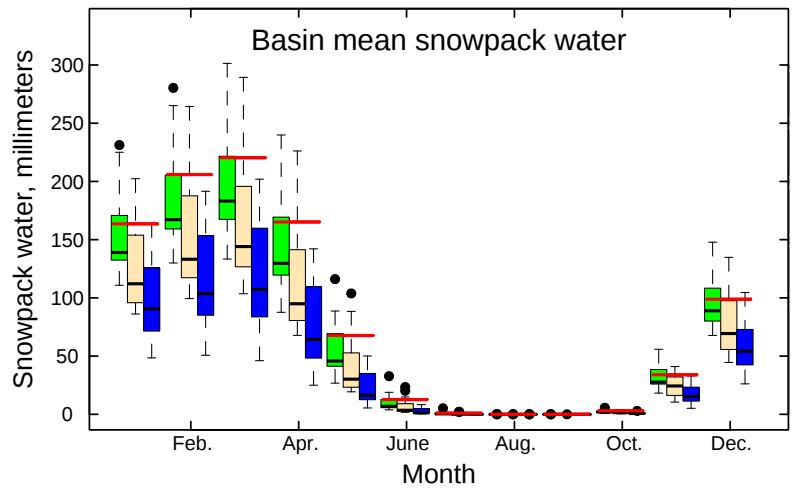

Figure 5. Mean daily snowpack water equivalent values by month for baseline conditions and projected range $(2030,2060$, and 2090) using the five General Circulation Models and three emission scenarios. 


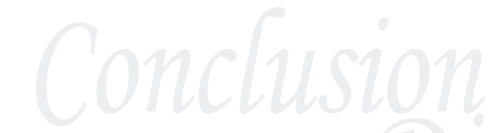

\section{Conclusion and Discussion}

Results from PRMS simulations for three emission scenarios of global climate change show dramatic seasonal changes in snow and rain dynamics for the Naches River Basin. The Naches River Basin is located in an elevation zone where a relatively small change in temperature can affect the precipitation form (rain or snow). Thus projected increase in air temperature results in increased winter runoff because the precipitation form changes from snow to rain. When precipitation falls as rain, it translates into streamflow more quickly than if it had fallen as snow and accumulated in the snowpack. More rain and less snow mean less runoff in the late spring and summer. This has large implications for water managers who rely on snowmelt from the spring snowpack to replenish reservoirs and provide early season irrigation. While annual runoff shows a slight increase in the global climate-change scenarios, spring runoff is less, and therefore, water managers may need to store more winter runoff to meet irrigation and instream flow demands throughout the year.

The effects of climate change in the Naches River Basin may alter the timing of streamflow and have the potential to change the conditions that support biological diversity in aquatic communities. The scientific techniques described in the fact sheet can be augmented with other techniques in developing decision support tools needed to address the effects of climate on streamflow regimes which in turn affects water temperature, bioenergetics, and aquatic habitats.

\section{Selected References}

Hay, L.E., Markstrom, S.L., and Ward-Garrison, C.D., 2011, Watershed-scale response to climate change through the twenty-first century for selected basins across the United States, Earth Interactions, v. 15, 37 p.

Intergovernmental Panel on Climate Change, 2007, Summary for policymakers, in Climate change 2007-The physical science basis, Contributions of Working Group 1 to the Fourth Assessment Report of the Intergovernmental Panel on Climate Change: Cambridge and New York, Cambridge University Press, $18 \mathrm{p}$.

Markstrom, S.L., Hay, L.E., Ward-Garrison, C.D., Risley, J.C., Battaglin, W.A., Bjerklie, D.M., Chase, K.J., Christiansen, D.E., Dudley, R.W., Hunt, R.J., Koczot, K.M., Mastin, M.C., Regan, R.S., Viger, R.J., Vining, K.C., and Walker, J.F., 2012, An integrated watershed scale response to climate change for selected basins across the United States: U.S. Geological Survey Scientific Investigations Report 2011-5077, 142 p.

Mastin, M.C., and Vaccaro J.J., 2002, Watershed models for decision support in the Yakima River Basin, Washington: U.S. Geological Survey Open-File Report 2002-404, 46 p.

Vaccaro, J.J., Jones, M.A., Ely, D.M., Keys, M.E., Olsen, T.D., Welch, W.B., and Cox, S.E., 2009, Hydrogeologic framework of the Yakima River basin aquifer system, Washington: U.S. Geological Survey Scientific Investigations Report 20095152, $106 \mathrm{p}$.

By Mark C. Mastin, Lauren E. Hay, and Steven L. Markstrom

For more information visit the following Web sites:

http://wwwbrr.cr.usgs.gov/projects/SW_MoWS/

http://wa.water.usgs.gov/

http://www.usgs.gov/climate_landuse/ 